JOURNAL OF MECHANICAL ENGINEERING, MANUFACTURES, MATERIALS AND ENERGY

Doi: $10.31289 /$ jmemme.v5i2.4629

Available online http://ojs.uma.ac.id/index.php/jmemme

\title{
Pengaruh Unsur Fe dan Penambahan Grain Refiner Al-5tib Terhadap Morfologi Fasa Intermetalik dan Sifat Mekanis pada Paduan Zamak 3
}

\section{Effect of Fe Element and Addition of Al-5tib Grain Refiner on Intermetallic Phase Morphology and Mechanical Properties of Zamak 3 Alloy}

\author{
Surya Irawan ${ }^{1)}$, Khairuddin Tampubolon ${ }^{2) *}$ \\ 1,2 Fakultas Teknik, Universitas Pembinaan Masyarakat Indonesia
}

Diterima: 18-12-2020 ; Disetujui: 07-08-2021 ; Diterbitkan: 30-12-2021

*Corresponding author: E-mail: khoir.tb@gmail.com

\begin{abstract}
Abstrak
Pada industri hot chamber diecasting pengunaan scrap bekas gating dan machining tidak pernah digunakan secara optimal untuk didaur ulang agar bisa menjadi raw material. Hal ini dikarenakan adanya unsur pengotor besi ( $\mathrm{Fe}$ ) membentuk fasa intermetalik yang ikut terlarut kedalam paduan $\mathrm{Zn}-\mathrm{Al}$ dan ini terlihat melalui struktur mikro. Sehingga mencul permasalahan yaitu akan mengakibatkan terjadinya cacat pada coran dan menurunkan sifat mekanis dari coran tersebut. Penelitian ini bertujuan untuk mengetahui pengaruh dari penambahan modifier Al-5TiB sebagai grain refiner merubah morfologi fasa intermetalik paduan.. Penelitian ini dilakukan di Departemen Metalurgi dan Material FTUI, Depok dan sebagai objeknya adalah Seng-Aluminium Zamak 3 dan Jenis Logam pendukung lainnya. Penelitian ini menggunakan metode eksperimental. Dari hasil penelitian diketahui pengaruh dari pengotor melalui penambahaan kadar besi (Fe) $0.04 \%$ dan $0.19 \%$ yang dapat mengakibatkan peningkatan fraksi fasa intermetalik pada batas butir yang menyebabkan penurunan kekuatan tarik, impak dan fluiditas pada paduan Seng - Aluminium. Penambahaan grain refiner Al-5TiB dengan 0.5\% dan 1\% pada master alloy Zamak 3 dengan kandungan besi (Fe) 0.19\% dapat membuktikan peningkatan sifat mekanis dan nilai fluiditas dari paduan Zamak 3. Akibat terbentuknya fasa intermetalik yang terdistribusi seragam dibatas butir yang lebih halus.
\end{abstract}

Kata Kunci: Besi (fe); Intermetalik, Logam; Scrap; Zamak 3

\begin{abstract}
In general, in the hot chamber diecasting industry the use of scrap gating and machining has never been optimally used for recycling so that it can become raw material. This is due to the presence of iron impurities (Fe) forming an intermetallic phase which is dissolved into the Zn-Al alloy which can be seen in its microstructure. So that problems arise that will result in defects in the castings and reduce the mechanical properties of the castings. This study aims to determine the effect of adding Al-5TiB modifier as a grain refiner in changing the morphology of the intermetallic phase of the alloy. This research was conducted at the Department of Metallurgy and Materials, FTUI, Depok and the objects were Zinc-Aluminum Zamak 3 and several other supporting metals. This study uses an experimental method. The results of the investigation show that the effect of impurities through the addition of iron (Fe) $0.04 \%$ and $0.19 \%$ can lead to an increase in the intermetallic phase fraction at the grain boundaries which causes a decrease in tensile strength, impact, and fluidity in Zinc - Aluminum alloys. The addition of 0.5\% and 1\% Al-5TiB grain refiner to the Zamak 3 master alloy with $0.19 \%$ iron ( Fe) content resulted in an increase in the mechanical properties and fluidity values of the alloy. This is due to the formation of an intermetallic phase which is more uniformly distributed over the finer grain boundaries.

Keywords: Iron (fe); Intermetallic; Metal; Scraps; Zamak 3
\end{abstract}


How to Cite: Irawan, S. 2021, Pengaruh Unsur Fe dan Penambahan Grain Refiner Al-5tib Terhadap Morfologi Fasa Intermetalik dan Sifat Mekanis pada Paduan Zamak 3, JMEMME (Journal of Mechanical Engineering, Manufactures, Materials and Energy), 5 (2): 96-114. 
Surya Irawan, Pengaruh Unsur Fe dan Penambahan Grain Refiner...

\section{PENDAHULUAN}

Proses hot chamber die casting merupakan proses pengecoran dengan mengunakan tekanan dimana pompa hidrolik berada dalam tungku dengan nozzle lalu logam cair ditekan masuk kedalam rongga ronga cetakan. Pada proses hot chamber diecasting ini biasanya paduan yang banyak dilebur adalah paduan Zn-Al jenis Zamak 3 dengan kadar aluminium sekitar 3.9 - 4.2 \% (standar ASTM B86). Paduan ini sering dipakai di awal tahun 2000 dan ini berkaitan dengan produk onderdil dan aksesoris pada otomotif serta untuk regulator Liquefied Petroleum Gas (LPG). Hal ini karena jenis paduan ini selain tahan karat dan mempunyai sifat mampu cor sangat baik dan mudah di elektroplating untuk menambah nilai estetika [1]. Pada paduan Zn-Al terdapat unsur pengotor seperti timbal, timah, antimoni, besi yang jika melebihi standar akan berpengaruh terhadap hasil produknya. Unsur besi (Fe) tersebut ditambahkan tanpa adanya pengetahuan mengenai efek jangka panjang maupun jangka pendek pada sifat paduan ini. Proses ini berubah berdasarkan hasil penelitian dari sebuah perusahaan pengecoran paduan seng yang berlokasi di New Jersey yang menyatakan bahwa unsur pengotor dapat membuat efek yang buruk bagi sifat mekanis pada paduan ini $[2,3,4]$.

Meskipun perkembangan teknologi bahan berkembang dengan pesat dan mengarahkan kepada pemakaian bahan-bahan yang ramah lingkungan seperti komposit, plastik, dan hibridnya $[5,6,7,8,9]$, tetapi untuk kasus-kasus tertentu penggunaan bahanbahan logam tetap tidak dapat dihindari. Oleh karena itu, diperlukan penyelidikan lebih lanjut untuk menghasilkan logam Fe dengan sifat-sifat mekanik yang lebih baik.

Rumusan Masalah dalam penelitian ini yaitu: adanya pengaruh Elemen pengotor besi (Fe) yang ada pada paduan seng cair tipe Zamak 3 terhadap morfologi fasa intermetalik dan sifat mekanis pada paduan zamak 3 [10], adanya unsur besi akan menimbulkan fasa intermetalik pada paduan seng dimana fasa intermetalik ini dalam jumlah banyak dapat menurunkan sifat mampu cor dan sifat mekanis [11], dan adanya unsur besi akan menimbulkan fasa intermetalik pada paduan seng dapat menyebabkan adanya cacat coran di dalam paduan [12].

Adapun tujuan dari penelitian ini ialah analisis pengaruh penambahan unsur Fe dan grain refiner Al-5Ti-B terhadap morfologi mikrostruktur paduan seng Zamak 3, analisis pengaruh penambahan unsur Fe dan grain refiner Al-5Ti-B terhadap fluiditas 
pada paduan seng Zamak, dan analsisi pengaruh penambahan unsur Fe dan grain refiner Al-5Ti-B terhadap nilai kekuatan mekanis pada paduan seng Zamak 3.

\section{METODE PENELITIAN}

Penelitian ini menggunakan metode ekpsperimental, yaitu suatu penelitian yang berusaha mencari pengaruh variabel tertentu terhadap variabel yang lain dalam kondisi terkontrol secara total. Pada metode ini, variabel - variabel dapat dikontrol sedemikian rupa, sehingga variabel luar yang mungkin mempengaruhi dapat dihilangkan.

Proses persiapan dan peleburan dalam penelitian ini dilakukan persiapan alat yang akan digunakan dan bahan yang akan di proses. Proses peleburan ingot Zamak 3 dilakukan setelah mendapat perhitungan komposisi kimia yang diinginkan pada saat peleburan untuk paduan seng. Dapur peleburan yang digunakan ialah Krusibel dengan tungku menggunakan bahan bakar briket batubara dan dibantu dengan blower. Paduan seng yang akan dilebur dengan ukuran volume furnace $5 \mathrm{~kg}$ dan dimasukkan secara bertahap. Setelah dilakukan perhitungan material balance selanjutnya dilakukan proses peleburan sampai titik temperatur tuang 420 0C lalu dituang cawan krusibel ukuran 200 gram dan lalu pengujian fluiditas dilakukan seperti diagram alir diatas dengan variabel yang sesuai. Unsur besi ditambahkan pada temperatur sekitar 4200C dan dilakukan pengadukan agar besi lebih merata ke seluruh seng cair. Penambahan Fe berbentuk serbuk halus (merck) kedalam krusibel agar dapat terlarut sempurna pada saat proses peleburan. Melalui proses pengadukan optimal sampai besi larut pada cairan paduan seng.

Penelitian ini dilakukan di Departemen Metalurgi dan Material FTUI, Depok. Pelaksanaan penelitian dimulai pada Maret 2020 sampai dengan Oktober 2020. Adapun objek penelitian ini adalah Seng-Aluminium Zamak 3 dan Jenis Logam pendukung lainnya. Teknik Pengumpulan Data penelitian ini menggunakan metode eksperimental, yaitu suatu penelitian yang berusaha mencari pengaruh variabel tertentu terhadap variabel yang lain dalam kondisi terkontrol secara total. Tingkat Kesiapterapan Teknologinya berupa: Data hasil penelitian. Tanzeh (2009) mengatakan bahwa data merupakan unit informasi yang direkam media yang dapat dibedakan dengan data lain, dapat dianalisis dan relevan dengan problem tertentu [13]. Nuryadi (2017) menyatakan bahwa data haruslah merupakan keterkaitan antara informasi dalam arti bahwa data harus 


\section{Surya Irawan, Pengaruh Unsur Fe dan Penambahan Grain Refiner...}

mengungkapkan kaitan antara sumber informasi dengan bentuk simbolik asli pada satu sisi [14].

Peralatan yang dipergunakan melakukan pengujian fluiditas ialah dapur peleburan tipe krusibel dan blower (gambar 1), kowi (gambar 2), Thermocouple jenis portable digital (gambar 3), alat uji fluiditas vakum (gambar 4), kompresor, cetakan ingot (gambar 5), Timbangan digital, Tang penjepit, dan sendok besi, Pemotong pipa, gerinda, dan gergaji besi, dan Peralatan keselamatan (masker dan sarung tangan).

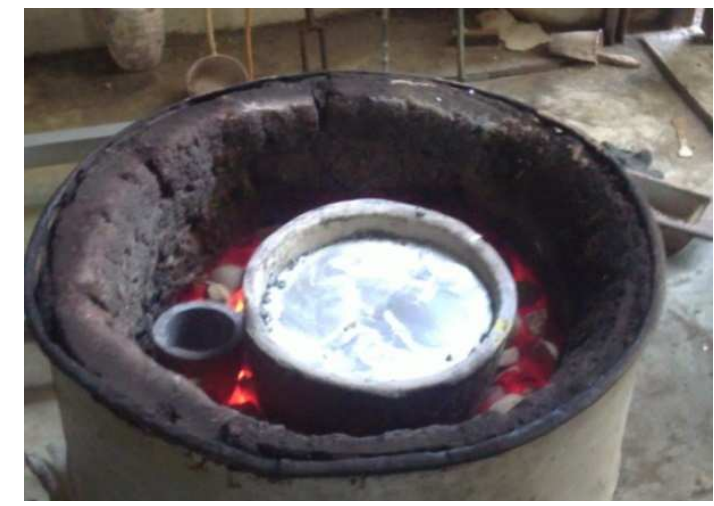

Gambar 1. Dapur peleburan tipe krusibel dan blower

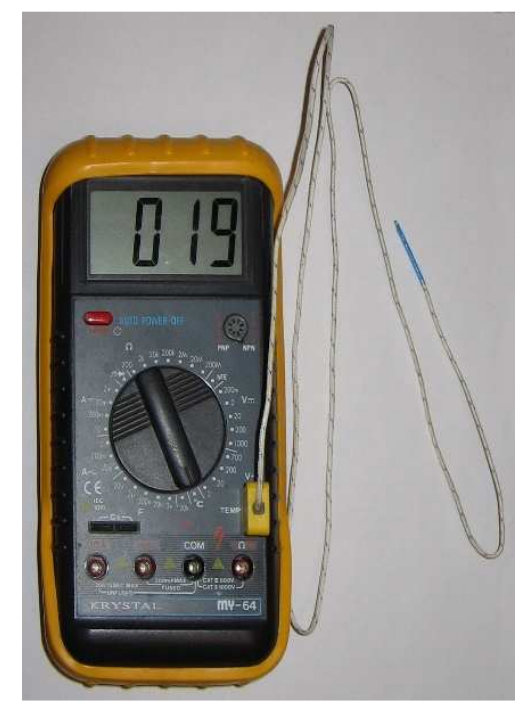

Gambar 3. Thermocouple (jenis portable digital)

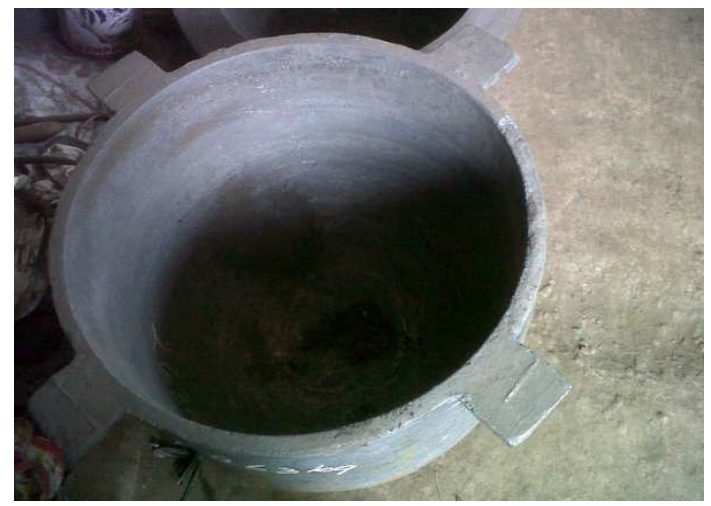

Gambar 2. Kowi

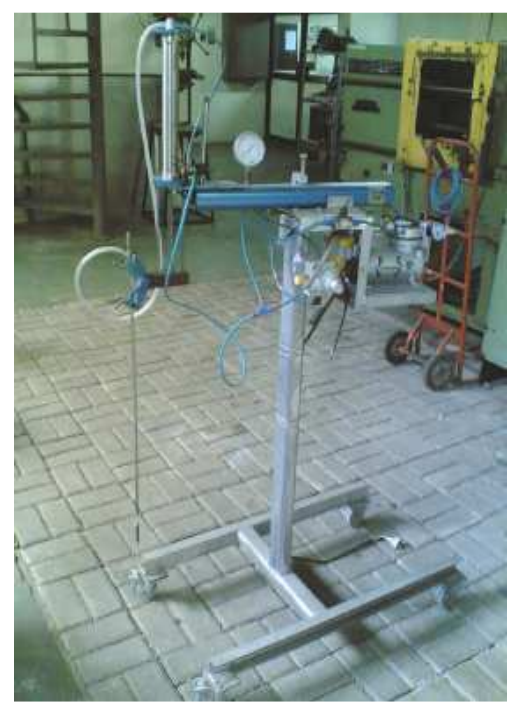

Gambar 4. Alat uji Fluiditas metode vacuum Section test 


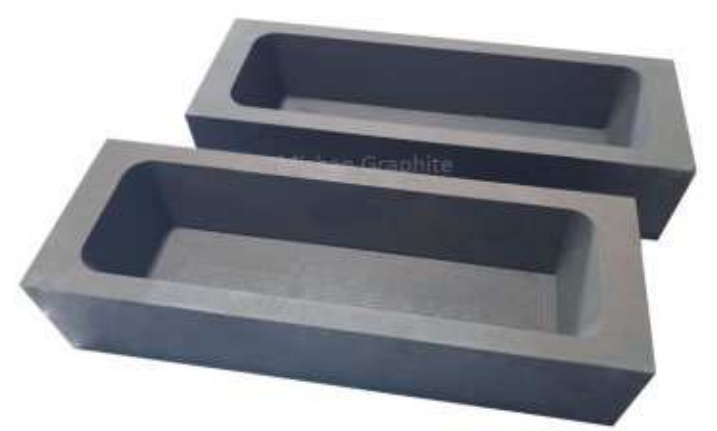

Gambar 5. Cetakan Ingot

Bahan yang digunakan untuk melakukan pengujian mampu alir (fluiditas) paduan ZAMAK, antara lain: Master alloy EDZA 3 96\% Zn dan 4\% Al (Gambar 6), Serbuk Fe merck (gambar 7), pipa tembaga, Flux coverall (gambar 8), Thermal coating, Resin dan hardener, kertas amplas 120\#, 240\#, 400\#, 600\#, 800\#, 1000\#, dan 1500\#, kain poles beludru dan zat poles Alumina, dan zat etsa Nital 1\% 1000 ml H20 (Gambar 9). Proses pemaduan serbuk besi, mempunyai parameter penelitian yang harus dijaga antara lain: menjaga serbuk besi dari angin agar tidak mengurangi komposisi pemaduan, dibutuhkan pengadukan yang lama agar serbuk besi melarut, dan pengaturan suhu yang tepat agar tidak terjadi losses pada paduan.

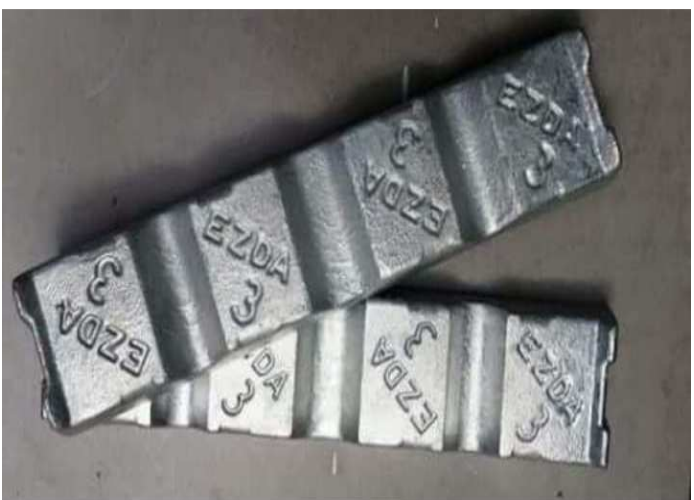

Gambar 6. alloy EDZA 3

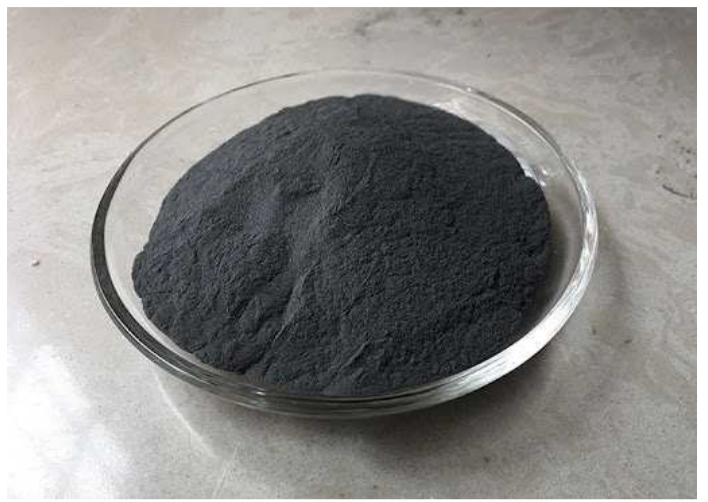

Gambar 7. Serbuk Besi (Fe) 


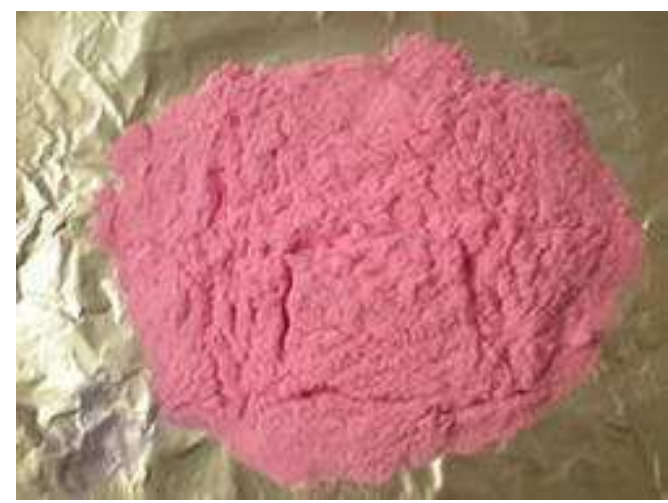

Gambar 8. Flux Coverall

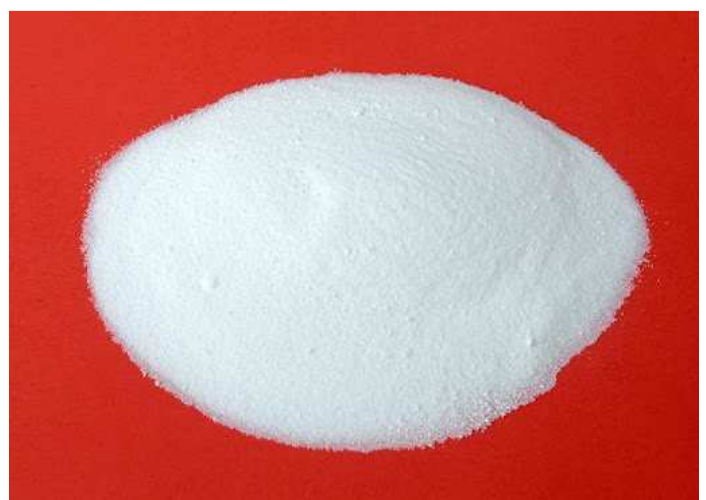

Gambar 9. Zat Etsa

\section{HASIL DAN PEMBAHASAN}

Penelitian ini dilakukan untuk mengamati perubahan nilai fluiditas beserta korelasinya dengan struktur mikro dan perubahan sifat mekanis dengan penambahan unsur pengotor Fe dan grain refiner Al-5TiB. Untuk medapatkan data - data terkait maka dilakukan serangkaian pengujian, berupa uji tarik, uji keras, uji impak, dan uji fluiditas.

Hasil pengujian komposisi kimia paduan Zamak 3 ditambah unsur Fe menunjukkan bahwa jumlah unsur aluminium pada ingot mencapai hingga 3,89\%. Data pengujian ini mengindikasikan bahwa paduan ingot yang akan digunakan sesuai dengan yang diinginkan. Perbandingan komposisi kimia Zamak 3 sebelum dan sesudah pencampuran dengan unsur besi (fe) diperlihatkan pada tabel 1 - 4 .

Tabel 1 Komposisi Kimia Zamak 3 sebelum dicampur unsur Besi (fe)

\begin{tabular}{cccccccccccc}
\hline & $\mathrm{Zn}$ & $\mathrm{Al}$ & $\mathrm{Cd}$ & $\mathrm{Cu}$ & $\mathrm{Fe}$ & $\mathrm{Mg}$ & $\mathrm{Mn}$ & $\mathrm{Ni}$ & $\mathrm{Pb}$ & $\mathrm{Si}$ & $\mathrm{Sn}$ \\
\hline 1 & 95,9 & 3,94 & 0,001 & 0,005 & $\mathbf{0 , 0 0 9}$ & $\mathbf{0 , 0 3 9 8}$ & 0,0009 & 0,002 & 0,002 & 0,001 & 0,0145 \\
2 & 96 & 3,88 & 0,001 & 0,003 & $\mathbf{0 , 0 0 7}$ & $\mathbf{0 , 0 3 7 5}$ & 0,0005 & 0,002 & 0,002 & 0,001 & 0,0115 \\
3 & 96,1 & 3,84 & 0,001 & 0,003 & $\mathbf{0 , 0 0 8}$ & $\mathbf{0 , 0 3 9 2}$ & 0,0005 & 0,002 & 0,002 & 0,001 & 0,006 \\
Ave & 96 & 3,89 & 0,001 & 0,004 & $\mathbf{0 , 0 0 8}$ & $\mathbf{0 , 0 3 8 8}$ & 0,0006 & 0,002 & 0,002 & 0,001 & 0,0107 \\
\hline
\end{tabular}

Tabel 2 Komposisi Zamak $3+0,04 \%$ Fe

\begin{tabular}{cccccccccccc}
\hline & $\mathrm{Zn}$ & $\mathrm{Al}$ & $\mathrm{Cd}$ & $\mathrm{Cu}$ & $\mathrm{Fe}$ & $\mathrm{Mg}$ & $\mathrm{Mn}$ & $\mathrm{Ni}$ & $\mathrm{Pb}$ & $\mathrm{Si}$ & $\mathrm{Sn}$ \\
\hline 1 & 96,3 & 3,54 & 0,001 & 0,004 & $\mathbf{0 , 0 5 5}$ & $\mathbf{0 , 0 0 0 4}$ & 0,0037 & 0,007 & 0,002 & 0,005 & 0,0173 \\
2 & 96,3 & 3,57 & 0,001 & 0,004 & $\mathbf{0 , 0 4 5}$ & $\mathbf{0 , 0 0 0 6}$ & 0,0044 & 0,003 & 0,002 & 0,004 & 0,0185 \\
3 & 96,3 & 3,58 & 0,001 & 0,004 & $\mathbf{0 , 0 3 2}$ & $\mathbf{0 , 0 0 0 6}$ & 0,0011 & 0,003 & 0,002 & 0,004 & 0,0134 \\
Ave & 96,3 & 3,56 & 0,001 & 0,004 & $\mathbf{0 , 0 4 4}$ & $\mathbf{0 , 0 0 0 5}$ & 0,0031 & 0,004 & 0,002 & 0,004 & 0,0164 \\
\hline
\end{tabular}

Tabel 3 Komposisi Kimia Zamak $3+0,19 \%$ Fe

\begin{tabular}{cccccccccccc}
\hline & $\mathrm{Zn}$ & $\mathrm{Al}$ & $\mathrm{Cd}$ & $\mathrm{Cu}$ & $\mathrm{Fe}$ & $\mathrm{Mg}$ & $\mathrm{Mn}$ & $\mathrm{Ni}$ & $\mathrm{Pb}$ & $\mathrm{Si}$ & $\mathrm{Sn}$ \\
\hline 1 & 96,7 & 3,13 & 0,001 & 0,006 & $\mathbf{0 , 1 9 7}$ & $\mathbf{0 , 0 0 1 6}$ & 0,0048 & 0,003 & 0,002 & 0,003 & 0,0033 \\
2 & 96,8 & 3,04 & 0,001 & 0,005 & $\mathbf{0 , 1 9 4}$ & $\mathbf{0 , 0 0 1 7}$ & 0,0021 & 0,004 & 0,002 & 0,003 & 0,0046 \\
3 & 96,8 & 3,05 & 0,001 & 0,004 & $\mathbf{0 , 1 8 2}$ & $\mathbf{0 , 0 0 1 4}$ & 0,0021 & 0,008 & 0,002 & 0,002 & 0,0046 \\
Ave & 96,8 & 3,07 & 0,001 & 0,005 & $\mathbf{0 , 1 9 1}$ & $\mathbf{0 , 0 0 1 6}$ & 0,003 & 0,005 & 0,002 & 0,003 & 0,0042 \\
\hline
\end{tabular}


Tabel 4 Perbandingan Komposisi Paduan Zamak 3; Fe 0\%,0, 04\% \& 0,19\%

\begin{tabular}{cccccccccccc}
\hline$\% \mathrm{Fe}$ & $\mathrm{Zn}$ & $\mathrm{Al}$ & $\mathrm{Cd}$ & $\mathrm{Cu}$ & $\mathbf{F e}$ & $\mathbf{M g}$ & $\mathrm{Mn}$ & $\mathrm{Ni}$ & $\mathrm{Pb}$ & $\mathrm{Si}$ & $\mathrm{Sn}$ \\
\hline 0 & 96 & $\mathbf{3 , 8 9}$ & 0,001 & 0,004 & $\mathbf{0 , 0 0 8}$ & $\mathbf{0 , 0 3 8 8}$ & 0,0006 & 0,002 & 0,002 & 0,001 & 0,0107 \\
0,04 & 96,3 & $\mathbf{3 , 5 6}$ & 0,001 & 0,004 & $\mathbf{0 , 0 4 4}$ & $\mathbf{0 , 0 0 0 5}$ & 0,0031 & 0,004 & 0,002 & 0,004 & 0,0164 \\
0,19 & 96,8 & $\mathbf{3 , 0 7}$ & 0,001 & 0,005 & $\mathbf{0 , 1 9 1}$ & $\mathbf{0 , 0 0 1 6}$ & 0,003 & 0,005 & 0,002 & 0,003 & 0,0042 \\
\hline
\end{tabular}

Pada table 2 dapat diketahui hasil pengujian komposisi kimia paduan Zamak 3 dengan ditambahkan sejumlah unsur besi dengan kadar yang diinginkan Fe 0,1\%, hanya mencapai diangka $0,04 \%$ hal tersebut terjadi dimungkinkan kurang lamanya proses mixing, sehingga serbuk besi tidak melarut semua. Pada table 3 diketahui pada paduan dengan kadar Fe yang diharapkan mencapai 0,2\%, mendapatkan nilai aktual 0,19\% hal tersebut dapat dinyatakan sesuai dengan nilai yang diharapkan. Pada setiap variabel, terjadi penurunan pada komposisi pemadu. Hal tersebut dapat dilihat pada Tabel 4 . Alumunium sebagai unsur pemadu terus mengalami penurunan hingga 3,07 \% dan pada magnesium, unsur ini juga mengalami penurunan hingga 0,0016 \%. Hal tersebut disebabkan pada pemaduan telah terjadi overheating sehingga pada kedua paduan tersebut mengalami oksidasi [15].

Komposisi Kimia Paduan Zamak 3 ditambah unsur Fe dan Al-5TiB diperlihatkan pada tabel 5. Setelah didapatkan paduan Zamak 3 + Fe 0,2\% maka dilakukan pengecoran pada cetakan sampel dan menuangkan paduan logam cair pada kowi yang sudah diletakkan tepat dibawah pipa tembaga untuk dilakukan pengukuran nilai fluiditas. Penambahan unsur Al-5TiB senilai 0,5\% dan 1\% disesuaikan dengan perhitungan material balance sehingga berat dari nugget Al-5TiB yang ditambahkan ditimbang dan diharapkan sesuai.

Tabel 5 Komposisi kimia paduan Zamak 3 dengan 0,19\% Fe dengan 0,5\% \& 1\% Al-5TiB

\begin{tabular}{ccccccccccc}
\hline $\begin{array}{c}\text { Penambah } \\
\text { an } \\
\text { Al-5TiB }\end{array}$ & Zn & Al & Cd & Cu & Fe & Mg & Mn & Ni & Pb & Sn \\
\hline $\mathbf{0 \%}$ & 96,8 & 3,07 & 0,002 & 0,005 & 0,191 & 0,0012 & 0,0003 & 0,005 & 0,002 & 0,0042 \\
$\mathbf{0 , 5 \%}$ & 93,79 & 5,773 & 0,005 & 0,137 & 0,19 & 0,0012 & 0,0068 & 0,002 & 0,002 & 0,0115 \\
$\mathbf{1 \%}$ & 92,29 & 7,377 & 0,008 & 0,021 & 0,19 & 0,0019 & 0,0077 & 0,002 & 0,002 & 0,006 \\
\hline
\end{tabular}

Hasil pengamatan struktur mikro pada paduan Zamak 3 ditambah unsur Fe dengan menggunakan mikroskop optik perbesaran 200X terlihat bahwa ada 2 fasa yang terbentuk pada paduan Zamak 3 antara lain fasa $\eta$-Zn dan $\alpha$-Al. Pada Gambar 10, daerah putih terang merupakan fasa $\eta$-Zn sebagai matriks $\mathrm{Zn}$ dan yang gelap ialah fasa $\alpha$-Al merupakan daerah yang mengandung Al. Menurut Anderson (E.A \& G.L, A New Zinc Alloy 
for Gravity Casting, 1962), juga menambahkan bahwa fasa $\alpha$-Al gelap berbentuk lamelar dan bersifat ulet sedangkan fasa $\eta$-Zn berbentuk dendrit dan memiliki kekerasan yang lebih dibandingkan fasa $\alpha-\mathrm{Al}$.

Menurut hasil uji komposisi dari tabel 4, terlihat bahwa komposisi aluminium berkurang setelah dilakukan penambahan Fe pada Zamak 3. Penambahan Fe pada paduan memicu terbentuknya fasa intermetalik dari paduan. Pada Gambar 10. B, jika dibandingkan dengan gambar 10.a, terdapat butir yang bulat mengkilap yang merupakan fasa intermetalik yang terbentuk. Menurut Taghiabadi (2009) fasa intermetalik yang terbentuk adalah FeAl3 pada temperature $520{ }^{\circ} \mathrm{C}[16,17]$. Oleh karena itu, dilakukan pengamatan struktur mikro dengan perbesaran 2000x untuk melihat lebih jelas bentuk fasa yang terbentuk serta analisa EDAX untuk mengetahui komposisi dari fasa tersebut.

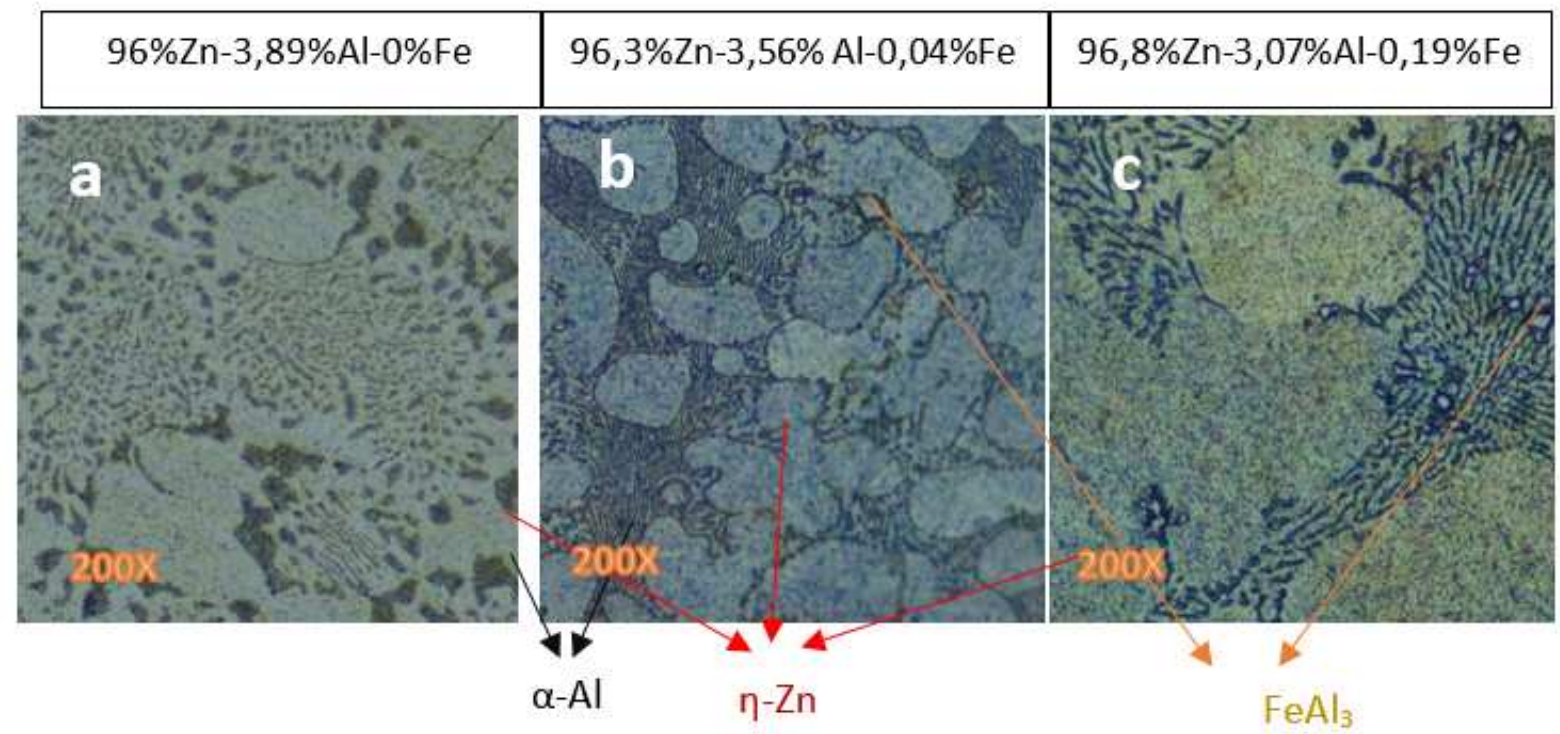

Gambar 10 Mikrostruktur Zamak 3 a) 0\% Fe b) 0,04\% Fe c) 0,19\% Fe perbesaran 200x dengan etsa Nital $1 \%$

Pada Hasil dari EDAX terlihat jelas bahwa terbentuknya fasa intermetalik pada perbesaran 2000x. Pada gambar 11 dan 12 terlihat bahwa terbentuk butiran - butiran kasar yang merupakan fasa intermetalik. Secara perbandingan terjadi peningkatan jumlah dan perbesaran fasa intermetalik pada peningkatan \% Fe.

Hasil EDAX pada Tabel 6 yang didapatkan sudah sesuai dengan literatur bahwa komposisi persen atom alumunium dengan besi adalah $3: 1$, pada perbandingan ini menjelaskan fasa intermetalik yang terbentuk adalah $\mathrm{FeAl}_{3}$ dan pada hasil EDAX dapat kita lihat terdapat persentase karbon, muncul kadar karbon ini terjadi karena, pada proses pretreatment dilakukan pembakaran. Yang dimungkinkan pembersihan yang kurang, sehingga karbon bekas - bekas pembakaran menyisa pada kowi. Pengukuran 
fraksi area dengan menggunakan software Image J dan tabel 6 pada kadar Fe 0,04\% fraksi area sebanyak 2,34\%, dengan kadar Fe 0,19\% sebanyak 4,81\%. Dengan peningkatan kadar Fe, luas area fasa intermetalik menjadi meningkat.

Tabel 6 Hasil EDAX dan pengukuran fraksi area pengaruh Fe pada fasa intermetalik

\begin{tabular}{cccc}
\hline \multirow{2}{*}{ Element } & \multicolumn{3}{c}{ At\% } \\
\cline { 2 - 4 } & $0,009 \mathrm{Fe}$ & $0,04 \mathrm{Fe}$ & $0,19 \mathrm{Fe}$ \\
\hline $\mathrm{C}$ & & 36.63 & 40.38 \\
$\mathrm{Al}$ & \multirow{3}{*}{ Tidak ada Intermetalik } & 44.52 & 42.21 \\
$\mathrm{Fe}$ & 10.51 & 11.71 \\
$\mathrm{Zn}$ & & 08.33 & 05.71 \\
Intermetalik & - & $\mathrm{FeAl}_{3}$ & $\mathrm{FeAl}_{3}$ \\
Fraksi Area & & $\mathbf{2 , 3 4 \%}$ & $\mathbf{4 , 8 1 \%}$ \\
\hline
\end{tabular}

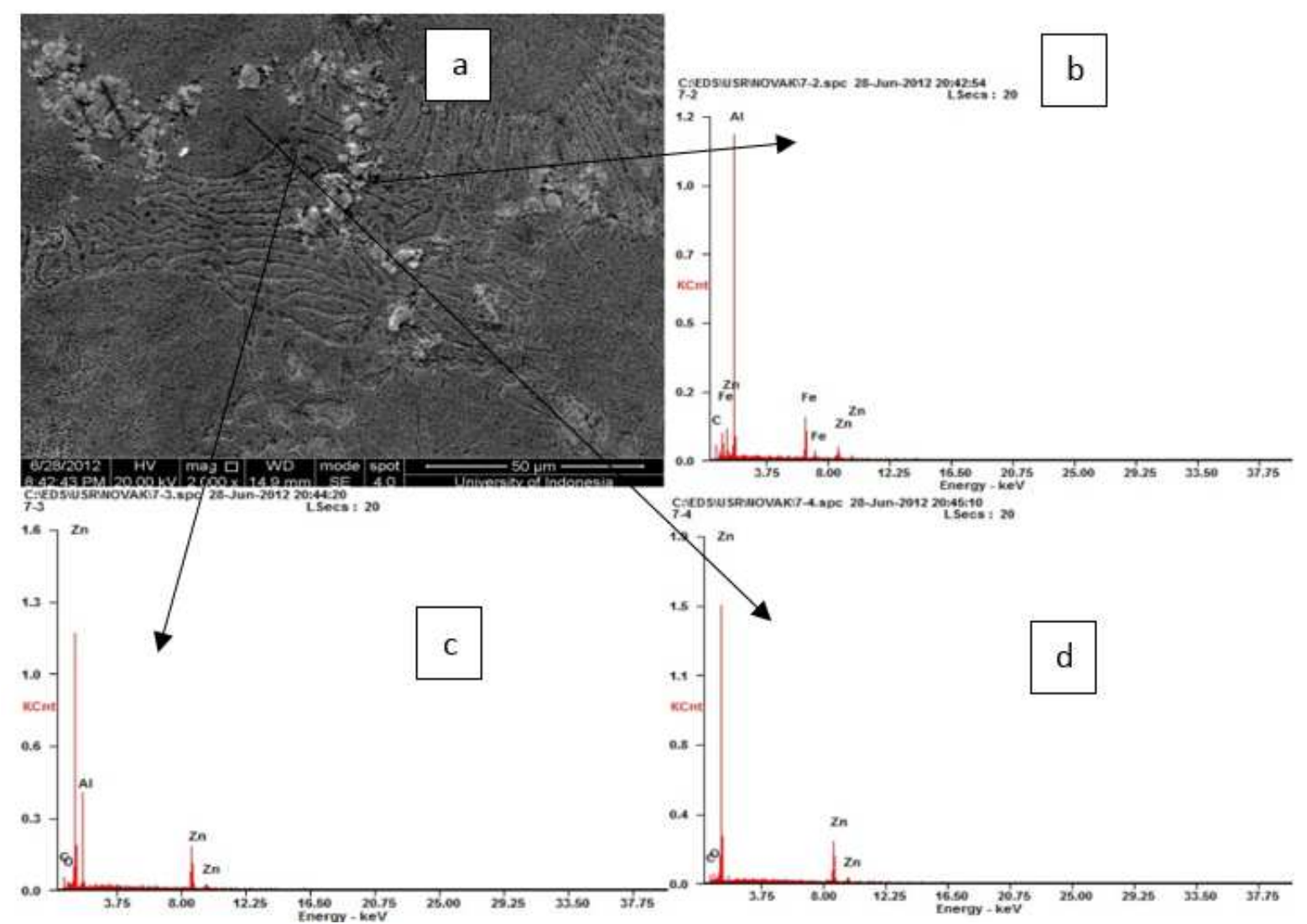

Gambar 11. Hasil SEM paduan Zamak 3 Fe 0,19\%, etsa CrO3, Na2S04, \& H2O. Hasil EDAX Pada; b) Fasa Intermetalik (FeAl3); c)Al rich; d) matriks $\mathrm{Zn}$

Hasil pengamatan struktur mikro pada paduan Zamak 3 dengan 0,19\%Fe dan Al5TiB dengan menggunakan mikroskop optik perbesaran 200X dapat terlihat pengaruh dari penambahan Al-5TiB. Menurut Wang Jianhua (2011), peningkatan kadar Al-5TiB akan menurunkan ukuran dan fraksi volume dari fasa $\eta$-Zn primer. Fasa dendritiknya menjadi butiran dan struktur lamellar dari $\alpha$-Al menipis $[18,19]$. 
Pada hasil pengamatan dengan mikroskop optik Gambar 12.a, daerah gelap yang berbentuk lamellar untuk menandakan daerah dari fasa $\alpha$-Al terlihat kurang jelas, tetapi pada Gambar 12.b, jelas terlihat fasa $\alpha$-Al dan bentuk dendritik dari fasa $\eta-Z n$. Setelah mengetahui kemungkinan fasa dan bentuk fasa yang terbentuk secara makro, dilakukan pengamatan struktur mikro dari hasil SEM dengan perbesaran 2000x untuk melihat lebih jelas bentuk fasa yang terbentuk serta analisa EDAX untuk mengetahui komposisi dari fasa tersebut.

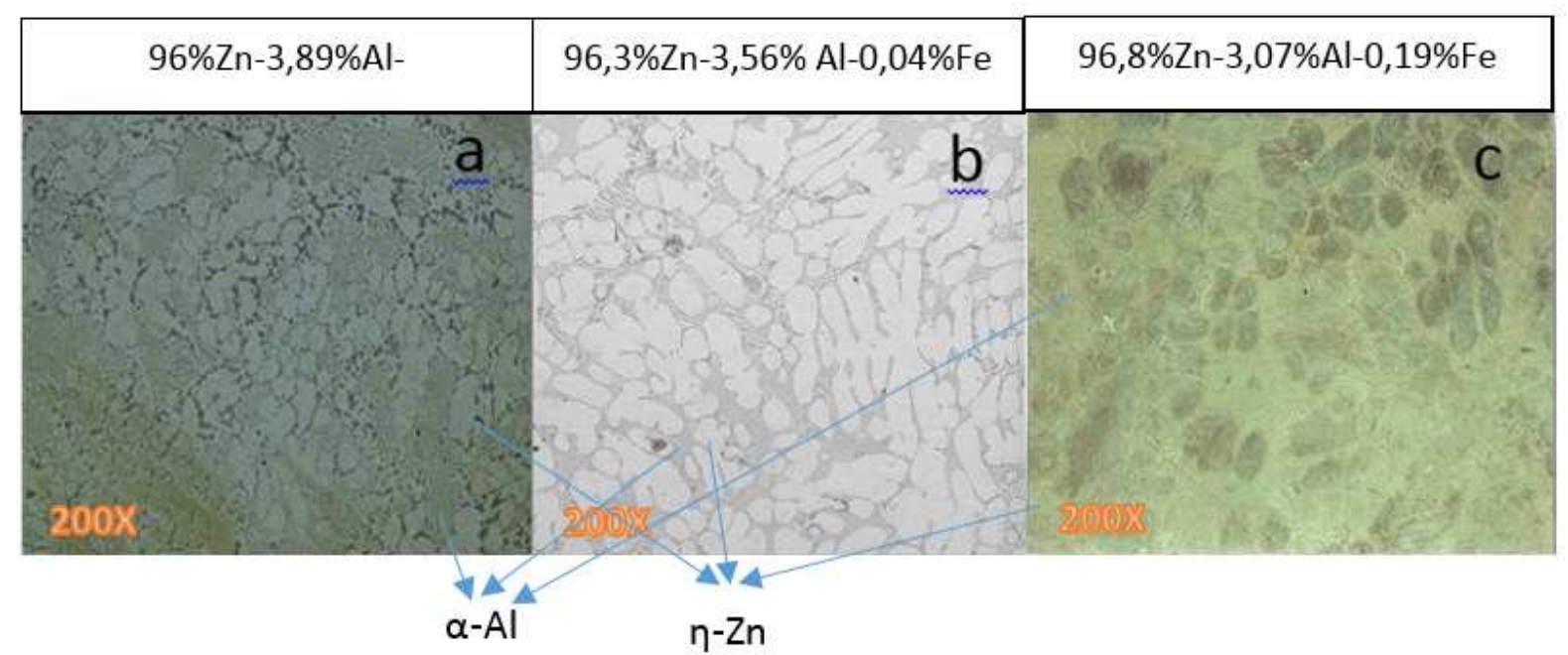

Gambar 12. Mikrostruktur Zamak 3 dengan Fe 2\% (a) 0\% Al-5TiB (b) 0,5\% Al-5TiB (c) 1\% Al$5 \mathrm{TiB}$ dengan Perbesaran 200x dengan etsa Nital 1\%

Hasil SEM DAN EDAX menunjukkan dengan penambahaan besi (Fe) $0.2 \%$ terbentuk fasa intermetalik yang mulai tersebar di batas butir (Gambar 13). Hal ini disebabkan oleh partikel dari $\mathrm{TiAl}_{3}$ dari Al-5TiB bertindak sebagai inti dari $\alpha$-Al akan memicu pembentukan nucleating site untuk dendrit primer dan menghasilkan butir yang halus dengan distribusi yang seragam. Peningkatan dari penambahan Al-5TiB menjadi 1\% pada gambar 11 juga dapat membuktikan pengaruh dari Al-5TiB terhadap mikrostruktur paduan.

Selain fasa $\eta$-Zn primer dan $\alpha$-Al, pernyataan dari Wang Jianhua tentang fasa intermetalik dari Al3Ti dan TiB2 yang berasal dari Al-5TiB, akan membantu nukleasi dan mengendalikan pertumbuhan butir dengan mengurangi ukuran butir aluminium. Pada Gambar 11 terlihat pada pengamatan dengan mikroskop butir yang bulat, namun pada pengamatan SEM terlihat banyak butir bulat kecil seperti inklusi. Setelah melihat hasil EDAX pada Gambar 14 barulah dapat diketahui bahwa butir bulat tersebut juga mengandung Zn. 

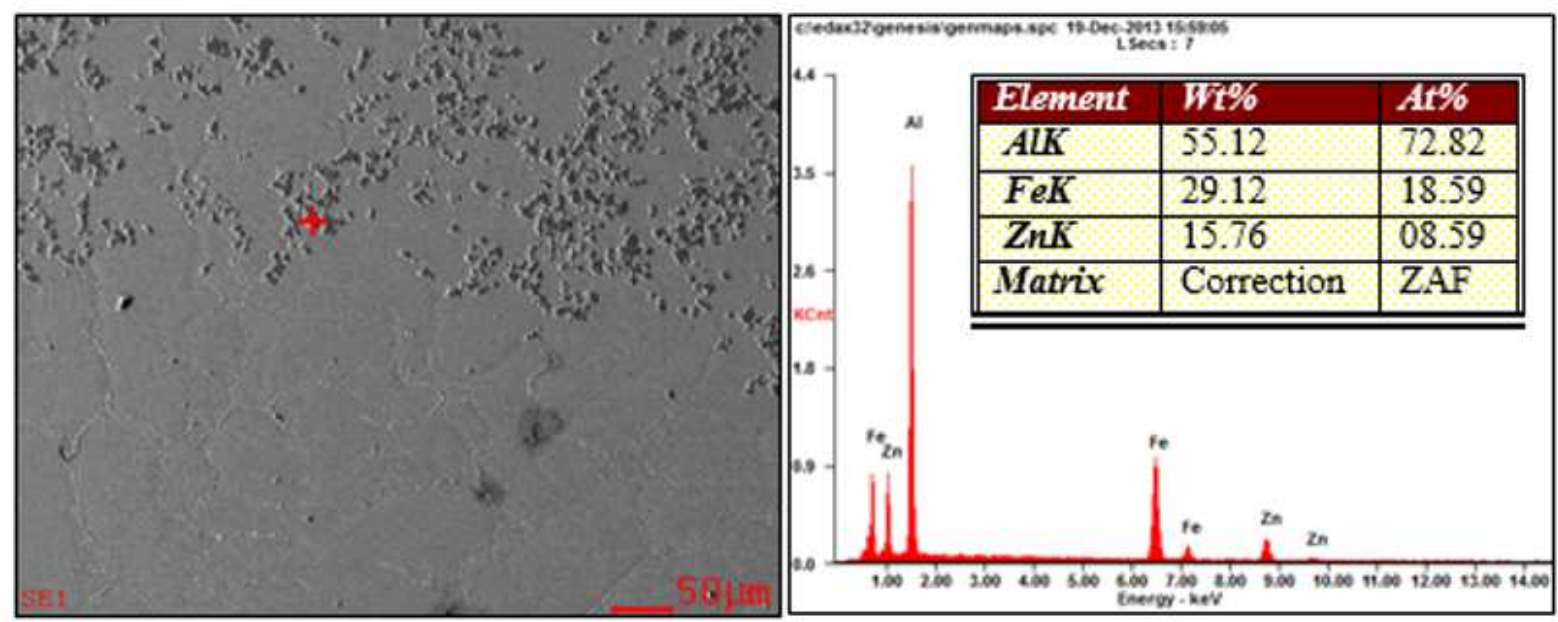

Gambar 13. Hasil SEM paduan Zamak $3 \mathrm{Fe} 0,2 \%$ dan Al-5TiB 0,5\% perbesaran 2000x dan hasil EDAX pada fasa Intermetalik ZnFeAl3
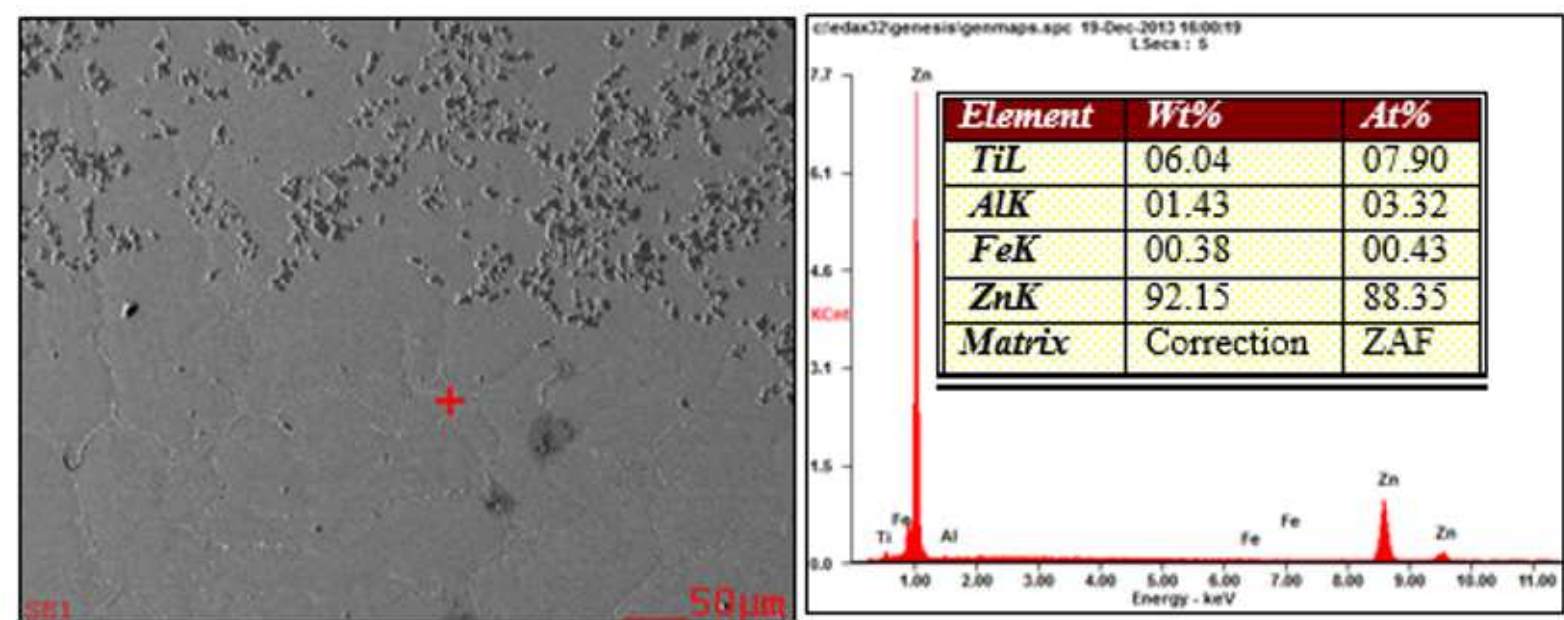

Gambar 14. Hasil SEM paduan Zamak $3 \mathrm{Fe} 0,2 \%$ dan Al-5TiB 0,5\% perbesaran 2000x dengan etsa Nital 1\% dan hasil EDAX pada fasa Intermetalik ZnAl3TiFe

Hal ini disebabkan oleh partikel dari TiAl3 dari Al-5TiB bertindak sebagai inti dari $\alpha$-Al akan memicu pembentukan nucleating site untuk dendrit primer dan menghasilkan butir yang halus dengan distribusi yang seragam. Peningkatan dari penambahan Al-5TiB menjadi 1\% pada gambar 15 juga dapat membuktikan pengaruh dari Al-5TiB terhadap mikrostruktur paduan.

Perhitungan fraksi intermetalik dengan menggunakan hasil SEM perbesaran 4000x dan menggunakan software Image J pada threshold 100 diperlihatkan pada gambar 16 18. Hasil analisa partikel sesuai dengan gambar dari partikel yang ditangkap oleh software diperlihatkan pada tabel 7. Dari hasil perhitungan kuantitatif dan kualitatif dari hasil analisa partikel intermetalik didapat hasil panjang, tebal, dan luas area partikel ratarata $4,34 \mu \mathrm{m}$. 
Surya Irawan, Pengaruh Unsur Fe dan Penambahan Grain Refiner...
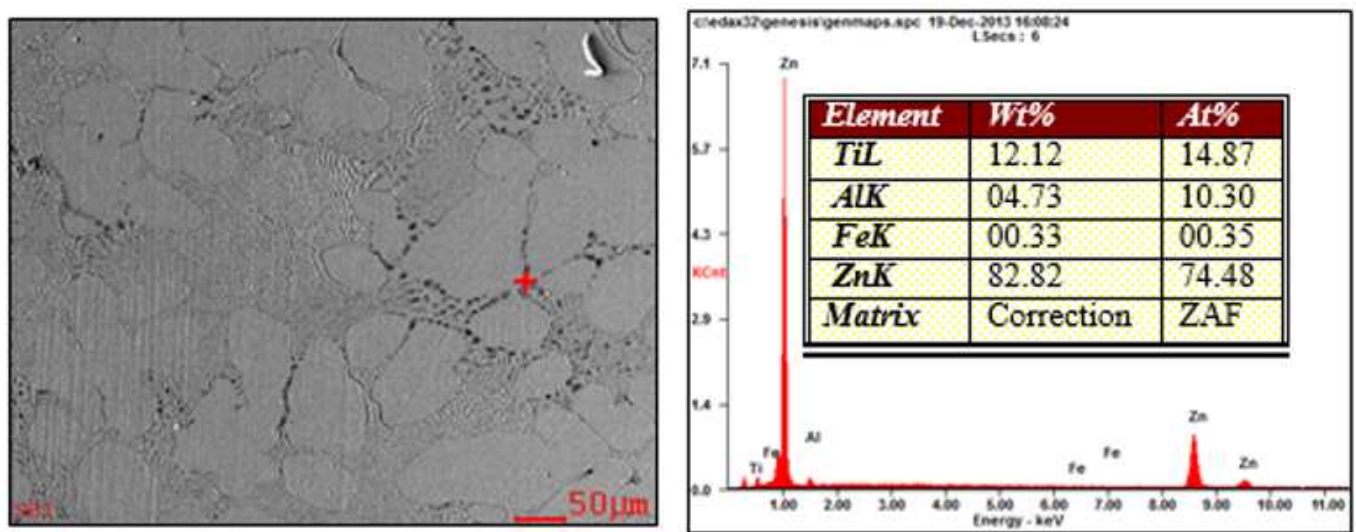

Gambar 15. Hasil SEM paduan Zamak 3 Fe 0,2\% dan Al-5TiB 1\% perbesaran 2000x dan hasil EDAX pada fasa Intermetalik ZnAl3TiFe

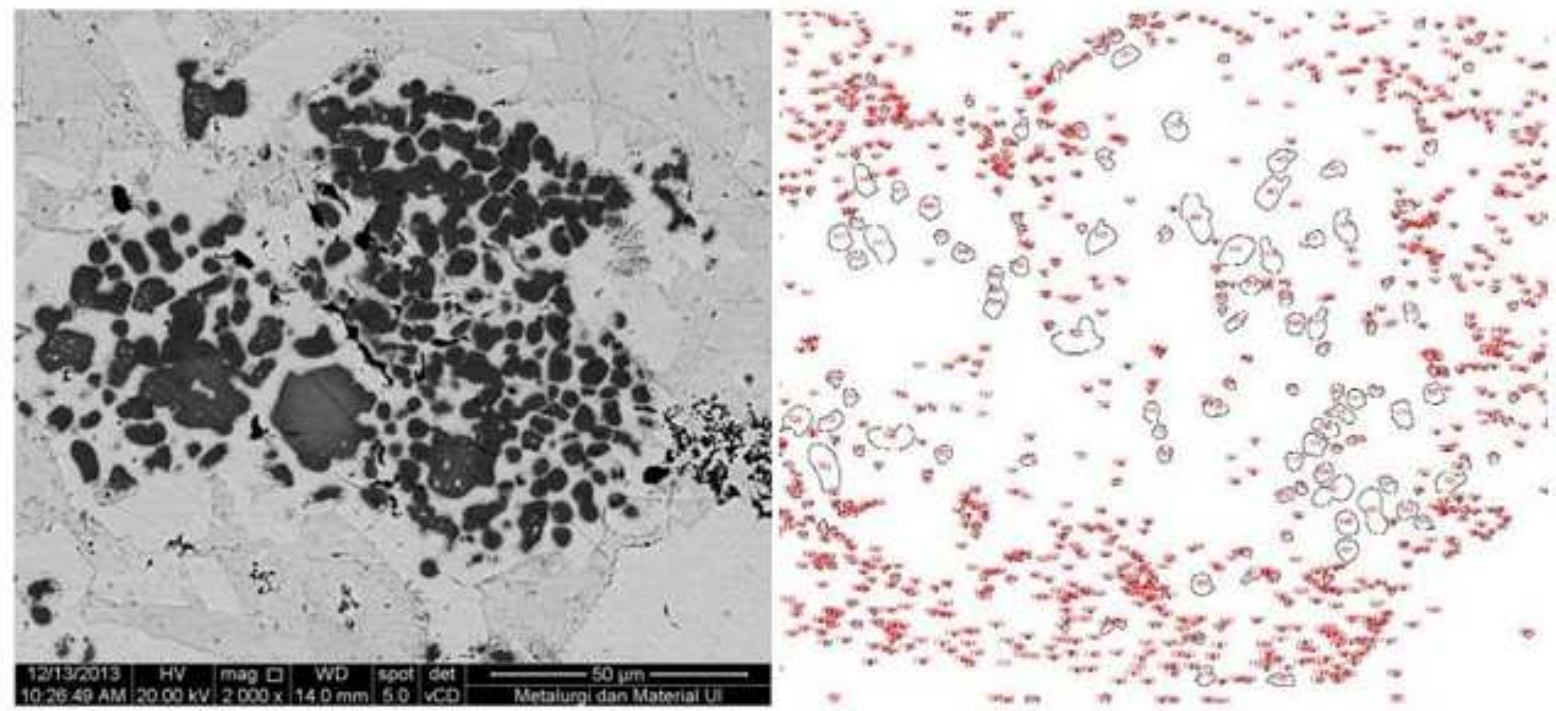

Gambar 16. Hasil SEM paduan Zamak 3 0,2\% tanpa penambahan Al-5TiB dengan hasil analisa partikel fasa intermetalik
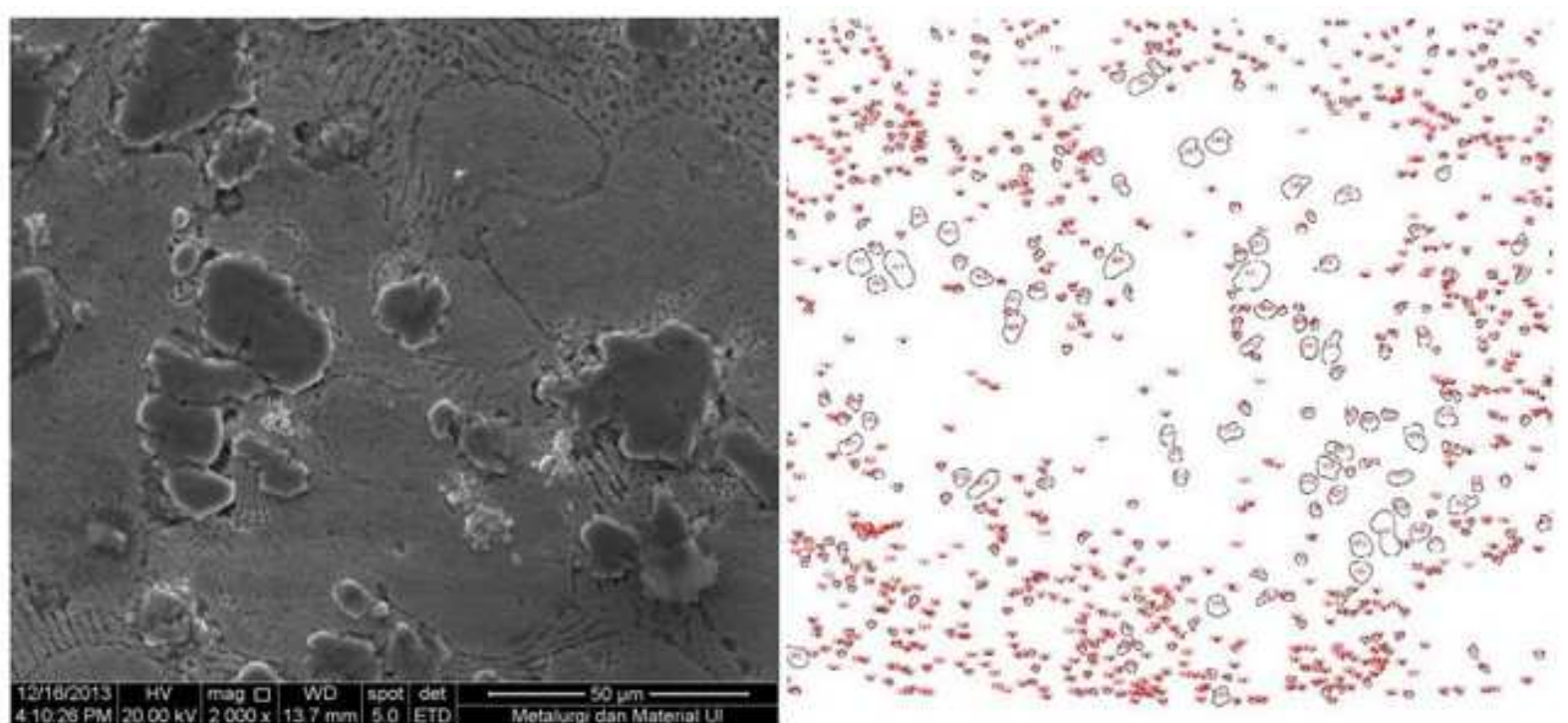

Gambar 17. Hasil SEM paduan Zamak 3 0,2\% dengan penambahan Al-5TiB 0,5\% dengan hasil analisa partikel fasa intermetalik 


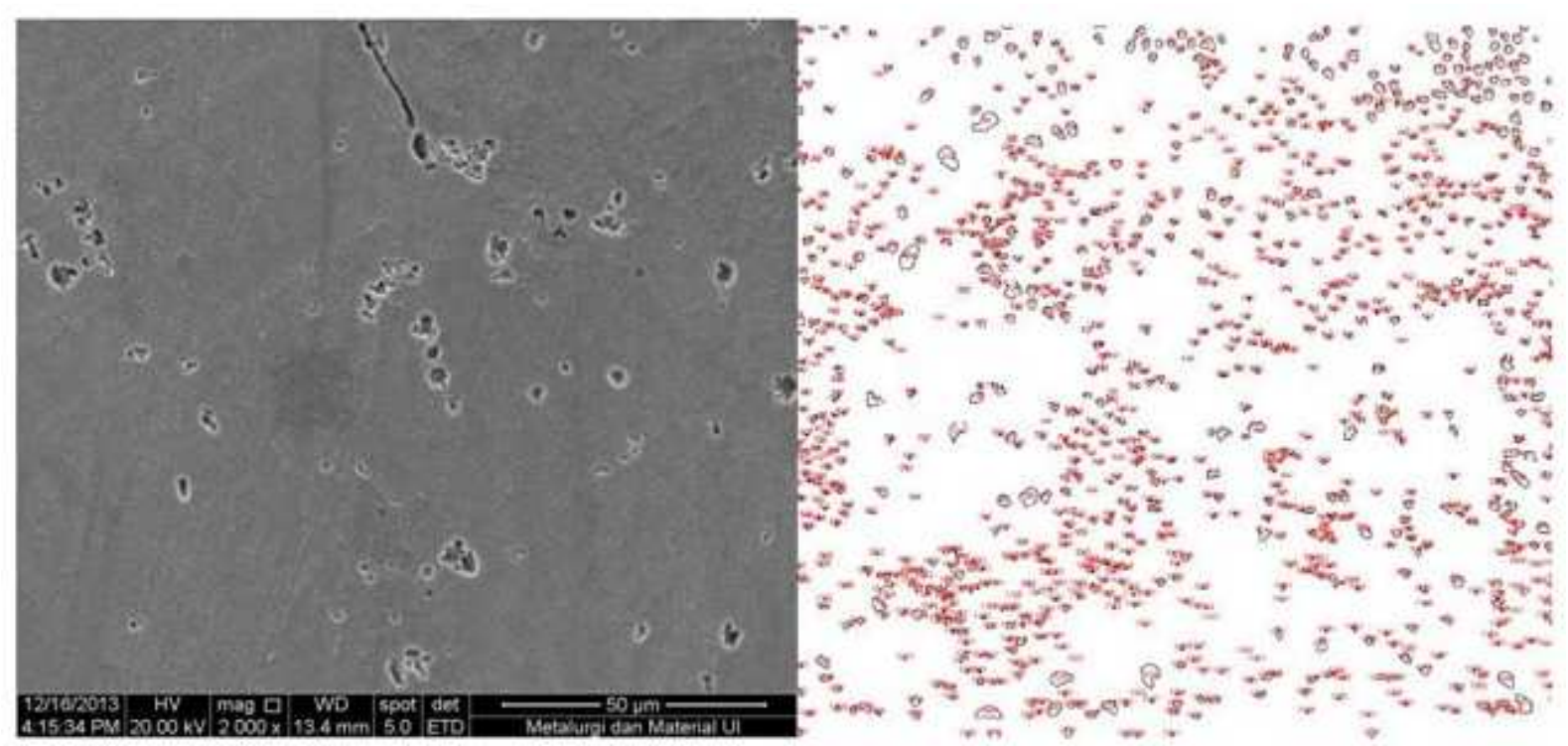

Gambar 18. Hasil SEM paduan Zamak 3 0,2\% dengan penambahan Al-5TiB 1\% dengan hasil analisa partikel fasa intermetalik

Tabel 7. Hasil analisa software Image J terhadap tebal dan panjang fasa intermetalik pada hasil EDAX paduan Zamak 3 Fe 0,2\% dengan penambahan kadar modifier Al-5TiB 0\%,0,5\%, dan 1\%

\begin{tabular}{cccc}
\hline Kadar Al-5TiB & $\mathbf{0 \%}$ & $\mathbf{0 , 5 \%}$ & $\mathbf{1 \%}$ \\
\hline Tebal $(\mu \mathrm{m})$ & 1.739 & 1.847 & 0.494 \\
Panjang $(\mu \mathrm{m})$ & 1.72 & 1.75 & 0.48 \\
Luas $\left(\mu \mathrm{m}^{2}\right)$ & 4.341 & 2.939 & 0.236 \\
\hline
\end{tabular}

Dari hasil perhitungan kuantitatif dan kualitatif dari hasil analisa partikel intermetalik didapat hasil panjang, tebal, dan luas area partikel rata-rata $2,39 \mu \mathrm{m}$. Pengurangan luasan dari 0\% Al-5TiB sebesar 32\%. Berdasarkan perhitungan tersebut juga diperoleh panjang, tebal, dan luas area partikel rata-rata $0.236 \mu \mathrm{m}$. Pengurangan luasan dari 0\% Al-5TiB sebesar 94,56\%.Dan pengurangan ini terjadi disebabkan penambahaan Al-5TiB dari0.5 \% dan $1 \%$ akan mempengaruhi fasa alpa-Zn sehingga terjadinya penghalusan butir sehigga fasa intermetalik halus menyebar dan seragam dibatas butir.

Faktor utama yang mempengaruhi fluiditas logam cair selain temperatur adalah komposisi. Hal lain yang menyebabkan nilai fluiditas terus menurun, disebabkan karena komposisi alumunium yang terus menurun seperti telah diperlihatkan pada tabel 4 . Alumunium meningkatkan fluiditas pada cairan logam dan meningkatkan castability. Komposisi alumunium pada paduan Zamak 3 Berkisar antara 3,5 - 4,3\%. Apabila komposisi alumunium kurang dari 3,5\% dibutuhkan suhu yang lebih tinggi dari standar yang telah ada untuk meningkatkan castability nya [20]. Sedangkan pada pengujian kali 
ini dilakukan dengan pada temperatur $700{ }^{\circ} \mathrm{C}$ pada setiap variabel melalui rata-rata 3 kali pengujian.

Pada gambar 19 terlihat bahwa nilai fluiditas terus menurun dari 27,5 cm hingga 21 cm seiring dengan penambahan Fe dari 0\% ke 0,19\%. Hal ini disebabkan oleh bertambah banyaknya jumlah inklusi yang berupafasa intermetalik berupa FeAl3 dan Fe2Al5 (Zn-Al$\mathrm{Fe}$ ) pada paduan yang dibuktikan dengan hasil analisa perhitungan luas area fraksi pada tabel 7. Fasa intermetalik ini menciptakan hambatan bagi aliran logam cair menuju ke cetakan.

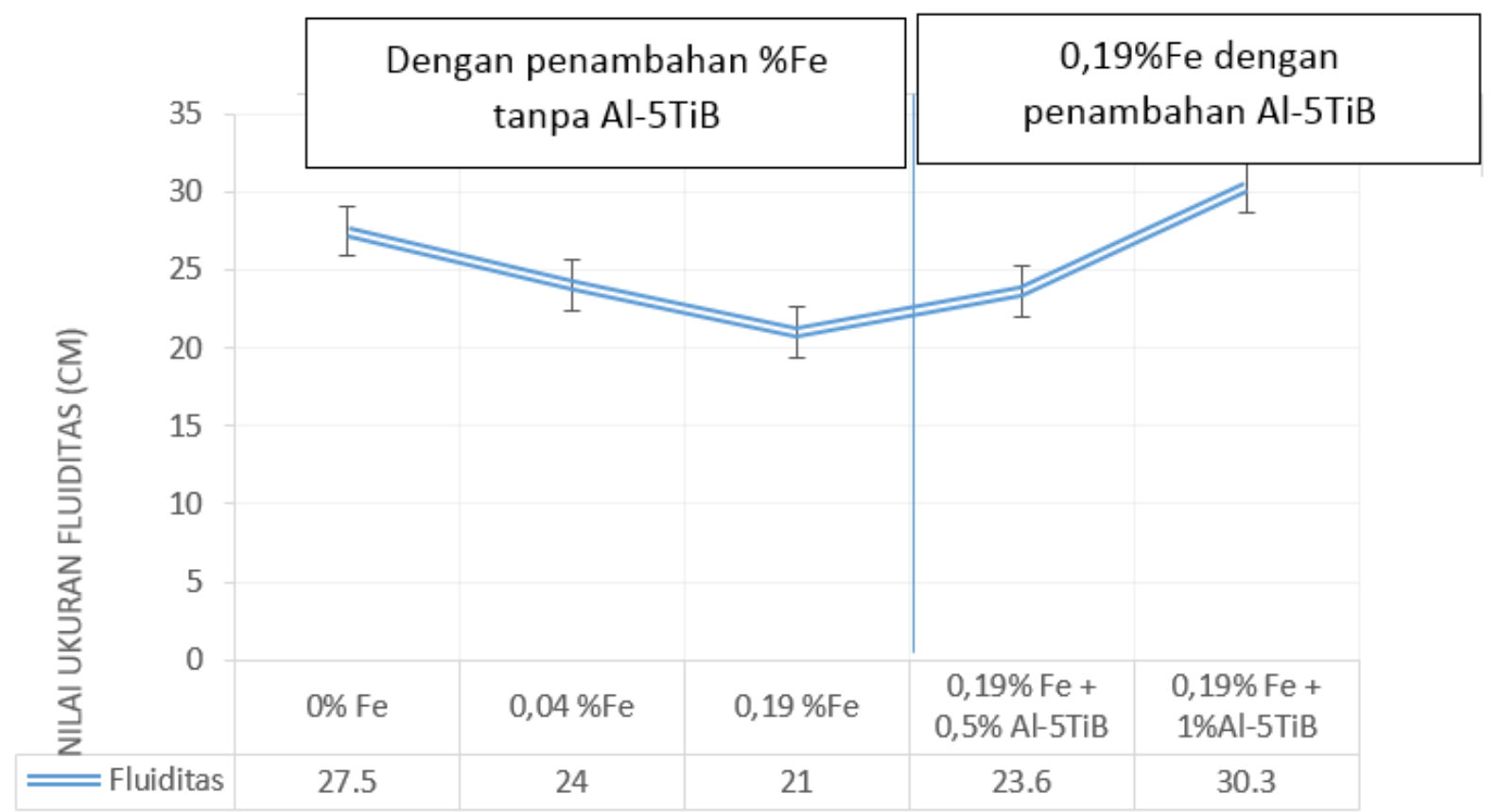

Gambar 19. Grafik pengaruh kadar Fe dan Al-5TiB terhadap nilai fluiditas Zamak 3 (0,19\%)

Sebaliknya, pada penambahan Al-5TiB ke dalam paduan dan mengurangi luasan area fasa intermetalik maka nilai fluiditas meningkat hingga 44\% sesuai dengan grafik yang ditunjukkan pada gambar 20. Penambahaan modifier grain refiner Al-5TiB $0.5 \%$ ke $1 \%$ pada diagram fasa pada gambar 21, unsur Fe membentuk fasa intermetalik berupa FeAl3 dan Fe2Al5 Fasa intermetalik ini menciptakan hambatan aliran logam cair menuju ke cetakan. Berdasarkan literatur fasa Fe2Al5 terbentuk pada komposisi Fe di bawah 5\%. Pada kadar dibawah 0,2\% Fe pada suhu $520{ }^{\circ} \mathrm{C}$ paduan zinc dapat melarutkan besi.

Selain komposisi dasar paduan, karakteristik komposisi lain juga mempengaruhi sifat mampu alir atau fluiditas, yaitu inklusi pada logam cair. Inklusi tersebut, yang berada dalam bentuk partikel tersuspensi tidak larut (suspended insoluble nonmetallic particle), akan menurunkan fluiditas Seng cair secara signifikan [21]. Inklusi oksida yang paling 
memungkinkan terjadi akibat lapisan oksida yang masih berada dalam keadaan padat ketika tergabung didalam fasa logam cair dan menghambat aliran logam cair (gambar 21). Hal tersebut terbukti dari hasil EDAX yang berada pada lampiran, munculnya komposisi karbon dan oksigen yang mengindikasikan terbentuknya karbida atau oksida logam.

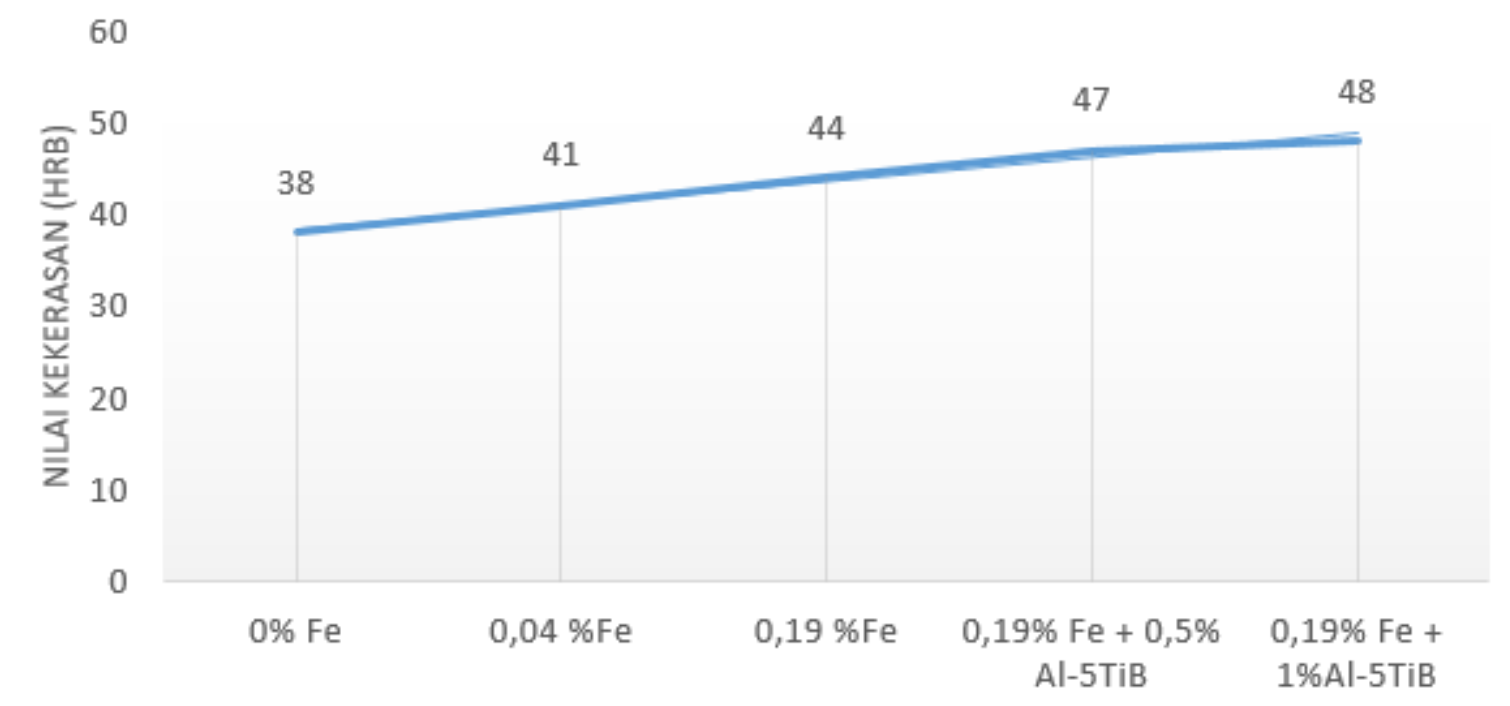

Gambar 20. Grafik pengaruh \%Fe dan penambahan \% Al-5TiB terhadap kekerasan Zamak 3 $(0,19 \%)$

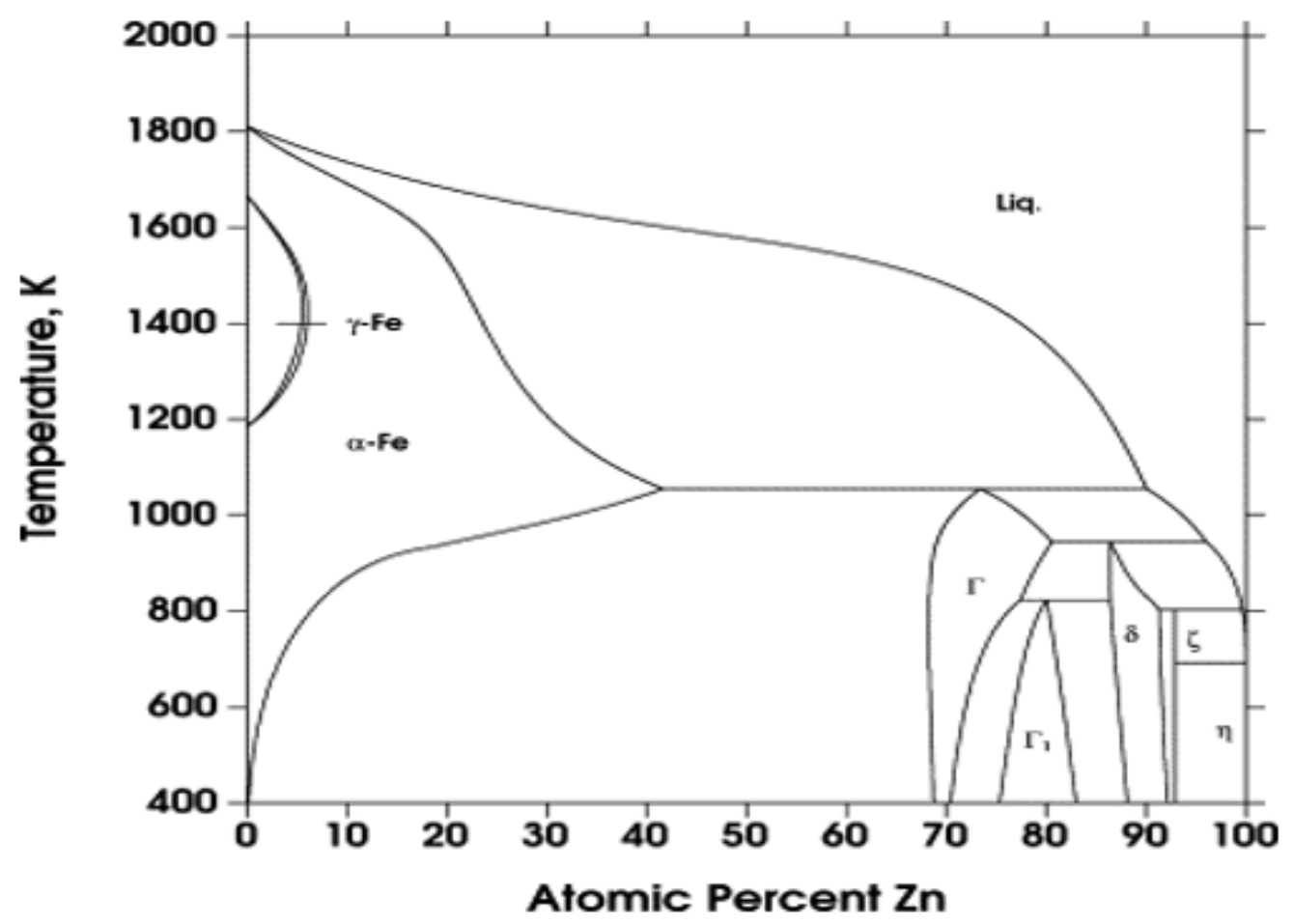

Gambar 21. Diagram Fasa Fe - Zn 
Surya Irawan, Pengaruh Unsur Fe dan Penambahan Grain Refiner...

\section{KESIMPULAN}

Penambahan Al-5TiB dalam paduan Zamak 3 yang sudah ditambahkan 0,19\% Fe menimbulkan variasi dari mikrostruktur paduan Zamak 3 modifikasi 0,19\% Fe.Mulai dari penambahan 0,5\% Al-5TiB, tampak bahwa fasa intermetalik FeAl3 mulai terdistribusi seragam pada batas butir. Fasa $\eta$ yang berbentuk pertumbuhan dendrit tampak equiaxed dan terisi oleh pertumbuhan fasa $\alpha$ eutektik yang lamelar dengan besar butir yang halus dan terlihat lebih baik pada saat penambahan 1\% Al-TiB. Analisa struktur mikro melalui tebal dan panjang fasa intermetalik dapat hasil panjang, tebal, dan luas area partikel rata - rata $2.39 \mu \mathrm{m} 2$ dan dengan penambahaan grain refiner Al-5TiB 0,5 \% didapat pengurangan luas sebesar $32 \%$ dan dengan penambahaan grain refiner Al-5TiB sebesar $1 \%$ rata- rata area partikel $0,236 \mu \mathrm{m} 2$. Pengurangan luas dari $0 \% \mathrm{Al}$-TiB ke $1 \%$ sebesar 94,56 \%. Penambahan Unsur Fe akan menurunkan nilai fluditas dari 27,2 hingga $21 \mathrm{~cm}$, dengan persentase penurunan sebanyak 22,7\%. Penambahan kadar Al-5TiB menyebabkan butir semakin bulat dan halus, sehingga nilai fluiditas dari paduan meningkat. Nilai fluiditas meningkat sebesar 44.28\% dari $21 \mathrm{~cm}$ hingga 30,3cm. Dari pengaruh kadar Fe pada cairan Seng paduan Aluminium terhadap turunnya nilai fluiditas dengan adanya peningkatan kadar Fe sehingga membentuk fasa intermetalik FeAl 3 ada dan terlihat pada diagram transformasi keseimbangan terner Zn-Al-Fe dalam cairan Seng Aluminium dan hal ini disebabkan juga karena adanya peningkatan kosentrasi dan pembesaran volume fasa intermetalik sehingga akan menciptakan hambatan aliran logam cair untuk menuju cetakan. Penambahan kadar Al-5TiB juga meningkatkan sifat mekanik dari paduan dengan antara lain, kekuatan tarik sebesar 89,39\% dari 44 MPa hingga 83,33 MPa dan Penambahan Al-5TiB akan meningkatkan kekuatan tarik sebesar 89,39\% dari $44 \mathrm{MPa}$ hingga 83,3 MPa karena bertumbuhnya fasa $\alpha$ eutektik yang bersifat lebih ulet dibandingkan fasa $\eta$.

\section{UCAPAN TERIMAKASIH}

Terima kasih kepada DIPA Direktorat Jenderal Pendidikan Tinggi, Kementerian Pendidikan, Kebudayaan, Riset dan Teknologi selaku penyandang dana penelitian melalui program SIMLITABMAS dan Semua pihak yang terlibat dalam kegiatan penlitian ini, semoga hasilnya memberikan manfaat untuk perkembangan ilmu pengetahuan dan teknologi. 


\section{REFERENSI}

[1] D. Suastiyanti, B. A. Topan and M. Wijaya, "Peningkatan Sifat Mekanis Al-Mg-Si dengan Proses Aging Untuk Aplikasi Selongsong Peluru," Jurnal Teknik Mesin ITI, vol. 3, no. 2, pp. 41-45, 2019.

[2] F. E. Goodwin, "Zinc Casting Alloys: Past, Present and Future," in NADCA 2008 Conference, Atlanta, 2008.

[3] A. Pola, M. Tocci and F. E. Goodwin, "Review of Microstructures and Properties of Zinc Alloys," Journal Metals, vol. 10, no. 2, pp. 2-16, 2020.

[4] F. E. Goodwin, K. Zhang and A. B. Filc, "Development of Zinc Die Casting Alloys with Improved Fluidity," in 111th Metalcastings Congress, Houston, 2007.

[5] M. Y. Yuhazri, A. J. Zulfikar and A. Ginting, "Fiber Reinforced Polymer Composite as a Strengthening of Concrete Structures: A Review," in 2nd International Conference in Industry and Manufacture Engineerin, Medan, 2020.

[6] A. J. Zulfikar, "The Flexural Strength of Artificial Laminate Composite Boards made from Banana Stems," Budapest International Research in Exact Sciences (BirEx) Journal, vol. 2, no. 3, pp. 334-340, 2020.

[7] A. J. Zulfikar, A. Sofyan and M. Y. Siahaan, "Numerical Simulation on The Onion Dryer Frame Capacity of $5 \mathrm{~kg} /$ hour," JMEMME (Journal of Mechanical Engineering Manufactures Materials and Energy), vol. 2, no. 2, p. 86-92, 2018.

[8] A. J. Zulfikar, B. Umroh and M. Y. R. Siahaan, "Design and manufacture of skateboard from banana stem," JMEMME (Journal of Mechanical Enggineering, Manufactures, Materials and Energy), vol. 3, no. 2, pp. 109-116, 2019.

[9] A. Rahmansyah and A. J. Zulfikar, "Manufacture of Water Pipe From Clampshell Powder Materials," JMEMME (Journal of Mechanical Engineering Manufactures Materials and Energy), vol. 2, no. 2, pp. 73-77, 2018.

[10] M. F. Ibrahim, S. A. Alkahtani, K. A. Abuhasel and F. H. Samuel, "Effect of intermetallics on the microstructure and tensile properties of aluminum based alloys: Role of $\mathrm{Sr}, \mathrm{Mg}$ and Be addition," Materials \& Design, vol. 86, pp. 30-40, 2015.

[11] Z.-Z. Shi, X.-X. Gao, H.-J. Zhang and X.-F. Liu, "Design biodegradable Zn alloys: Second phases and their significant influences on alloy properties," Bioactive Materials, vol. 5, no. 2, pp. 210-218, 2020.

[12] S. G. Irizalp and N. Saklakoglu, "Effect of Fe-rich intermetallics on the microstructure and mechanical properties of thixoformed A380 aluminum alloy," Engineering Science and Technology, vol. 17, no. 2, pp. 58-62, 2014. 
Surya Irawan, Pengaruh Unsur Fe dan Penambahan Grain Refiner...

[13] A. Tanzeh, Pengantar Metode Penelitian, Malang: Teras, 2009.

[14] N. Nuryadi, T. D. Astuti, E. S. Utami and M. Budiantara, Dasar-dasar Statistik Penelitian, Yogyakarta: Gramasurya, 2017.

[15] M. Schoenitz, B. Patel, O. Agboh and E. L. Dreizin, "Oxidation of aluminum powders at high heating rates," Thermochimica Acta, vol. 507, pp. 115-122, 2010.

[16] E. Taghaddos, M. Hejazi, R. Taghiabadi and S. Shabestari, "Effect of iron-intermetallics on the fluidity of 413 aluminum alloy," Journal of Alloys and Compounds, vol. 468, no. 2, pp. 539-545, 2009.

[17] k. tampubolon and F. R. Koto, "ANALISIS PERBANDINGAN EFISIENSI KERJA MESIN BENSIN PADA MOBIL TAHUN 2000 SAMPAI TAHUN 2005 DAN MOBIL TAHUN 2018 SERTA PENGARUH TERHADAP KONSUMSI BAHAN BAKAR DAN CARA PERAWATANNYA SEBAGAI REKOMENDASI BAGI KONSUMEN," JMEMME OJOURNAL OF MECHANICAL ENGINEERING, MANUFACTURES, MATERIALS AND ENERGY), vol. 3, no. 2, pp. 76-83, 2019.

[18] W. Jianhua, W. Xiande, T. Hao and S. Xuping, "Effect of titanium on microstructures and mechanical properties of ZnAl4Y alloy," China Foundry, vol. 65, pp. 397-400, 2011.

[19] W. Elbar and k. tampubolon, "PENGARUH CAMPURAN SILIKON PADA ALUMINIUM TERHADAP KEKERASAN DAN TINGKAT KEAUSANNYA," JMEMME OJOURNAL OF MECHANICAL ENGINEERING, MANUFACTURES, MATERIALS AND ENERGY), vol. 4, no. 2, pp. 183-196, 2020.

[20] P. Beeley, Foundry Technology, Oxford: Butterworth-Heinemann, 2001.

[21] M. D. Sabatino, L. Arnberg, S. Rørvik and A. Prestmo, "Entrapment of inclusions in continuous casting billet: Industrial observation and modeling," The influence of oxide inclusions on the fluidity of Al-7 wt.\%Si alloy, vol. 414, pp. 272-276, 2005.

[22] A. J. Zulfikar and M. Y. R. Siahaan, "Investigation of Mechanical Behavior of Polymeric Foam Materials Reinforced by Oil Palm Empty Fruit Bunches (OPEFB) Fibers Due to Static and Dynamic Loads," JOURNAL OF MECHANICAL ENGINEERING MANUFACTURES MATERIALS AND ENERGY, vol. 3, no. 1, pp. 10-19, 2019. 